\title{
De vordering tot vergoeding van koersgerelateerde schade geleden door aandeelhouders en optiebeleggers
}

Over afgeleide schade van aandeelhouders en 'dubbel afgeleide' schade van optiebeleggers

Mr. H.W. Haksteeg en Mr. drs. A.C.W. Pijls ${ }^{1,2}$

\begin{abstract}
Bij koersschade dient onderscheid te worden gemaakt tussen schade die beleggers direct lijden als gevolg van misleidende berichtgeving en schade die zij indirect lijden als gevolg van de normschending van een derde jegens de beursvennootschap. Laatstgenoemde afgeleide of 'dubbel afgeleide' schade komt slechts in zeer uitzonderlijke gevallen voor vergoeding in aanmerking. De auteurs behandelen beide vormen van afgeleide schade en de bijbehorende Poot/ABPdoctrine en bespreken de (al-dan-niet) vergoeding van directe en 'dubbel afgeleide' schade geleden door optiebeleggers.
\end{abstract}

\section{$1 \quad$ Inleiding}

Beleggers op de beurs kunnen koersschade lijden, als zij door de vennootschap waarin zij direct of indirect beleggen direct of indirect worden misleid, of als een derde (waaronder te verstaan de bestuurder) jegens de vennootschap wanprestatie of een onrechtmatige daad (hierna: O.D.) pleegt met schade van de vennootschap tot gevolg. Beleggers die koersschade lijden, kunnen proberen deze schade te verhalen door de vennootschap, de bestuurder(s) en/of andere betrokken derden hiervoor aansprakelijk te stellen. Als een beursvennootschap zich schuldig maakt aan misleiding van het beleggende publiek, lijden de beleggers die hierdoor worden benadeeld zogenoemde 'directe' of 'rechtstreekse' schade. In de situatie daarentegen waarin een derde jegens de vennootschap wanprestatie of een O.D. pleegt met schade van de vennootschap tot gevolg, lijden - bij het bekend worden van deze schade - aandeelhouders zogenoemde 'afgeleide' schade. Daarnaast kunnen beleggers in financiële instrumenten die van de door de vennootschap uitgegeven aandelen zijn afgeleid (denk aan optiebeleggers) dan schade lijden die weer van de afgeleide schade van de aandeelhouder is afgeleid. In het laatste geval kan ook wel worden gesproken van zogenoemde 'dubbel afgeleide' schade van de optiebelegger. Voor optiebeleggers kan een daling van de aandelenkoers resulteren in het waardeloos aflopen van hun optie, waardoor hun initiële investering geheel verloren gaat.

In dit artikel bespreken wij de mogelijkheden van aandeelhouders en optiebeleggers om koersschade die zij direct of indirect - met 'indirect' bedoelen wij hier afgeleid of dubbel afgeleid - hebben geleden, vergoed te krijgen. Vooral onze analyse van de vordering van optiebeleggers tot vergoeding van door hen geleden 'dubbel afgeleide' schade voegt een

\footnotetext{
${ }^{1}$ Walther Haksteeg heeft recent zijn master Ondernemingsrecht afgerond aan Erasmus School of Law ('ESL'). Arnoud Pijls is universitair docent Ondernemingsrecht en Financieel recht aan ESL. Dit artikel vormt een bewerking van hoofdstuk 3 van de scriptie 'Schadeverhaal voor optiebeleggers na misleiding door beursvennootschappen' van eerstgenoemde auteur. De scriptie is te raadplegen via de volgende link: https://repub.eur.nl/pub/130417.

${ }^{2}$ Met dank aan Bastiaan Assink, Marnix Hebly, Matthijs de Jongh, Erik de Kloe, Olivier Oost en Vino Timmerman voor hun waardevolle commentaar op een eerder concept.
} 
nieuwe dimensie toe aan de discussie over de bekende Poot/ABP-doctrine en afgeleide schade van aandeelhouders. Hoewel ons nog geen uitspraken bekend zijn waarin een vordering tot vergoeding van 'dubbel afgeleide' schade geleden door optiebeleggers wordt toe- of afgewezen, is onze analyse ook voor de praktijk van belang. Zo zal in de situatie waarin een optiebelegger vergoeding vordert van door hem geleden directe schade, deze directe schade moeten worden onderscheiden van eventueel door hem geleden 'dubbel afgeleide' schade.

De opbouw van dit artikel is als volgt. In paragraaf 2 gaan wij eerst in op het onderscheid tussen directe en afgeleide schade geleden door aandeelhouders. In paragraaf 3 bespreken wij daarna de Poot/ABP-doctrine en haar ratio. In paragraaf 4 behandelen wij het geval waarin de aandeelhouder de vennootschap - in plaats van de derde die een norm jegens de vennootschap heeft geschonden - aanspreekt tot vergoeding van zijn afgeleide schade en waarin hij zich op het standpunt stelt dat de handelingen van de derde aan de vennootschap kunnen worden toegerekend. In paragraaf 5 gaan wij in op de bekende uitzondering van de hoofdregel uit het Poot/ABP-arrest: de aandeelhouder stelt dat de derde jegens hem een specifieke zorgvuldigheidsnorm heeft geschonden. paragraaf 6 bevat een intermezzo over de optiemarkt en de werking van opties. In paragraaf 7 beantwoorden wij de vraag of directe en 'dubbel afgeleide' schade van optiebeleggers voor vergoeding in aanmerking komen, en wij analyseren in dat verband de (al-dan-niet)toepassing van de Poot/ABP-doctrine op laatstgenoemde 'dubbel afgeleide' schade. In paragraaf 8 maken wij tot besluit enkele concluderende opmerkingen.

Vooraf merken wij op dat wij ons in dit artikel beperken tot de vordering tot vergoeding van directe, afgeleide of 'dubbel afgeleide' schade geleden door beleggers die direct of indirect beleggen in beursvennootschappen. In het vervolg van dit artikel zullen wij in beginsel steeds refereren aan de 'vennootschap', maar daarmee bedoelen wij dus de 'beursvennootschap'. Daaronder verstaan wij de naamloze of besloten vennootschap naar Nederlands recht waarvan aandelen of certificaten van aandelen zijn toegelaten tot de handel op een gereglementeerde markt als bedoeld in artikel 1:1 Wft of een multilaterale handelsfaciliteit als bedoeld in artikel 1:1 Wft. Hoewel wij ons in dit artikel zoals gezegd beperken tot koersschade geleden door beleggers in beursvennootschappen, is onze analyse in paragraaf 2 tot en met 5 van de Poot/ABP-doctrine en afgeleide schade van aandeelhouders van overeenkomstige toepassing op afgeleide schade geleden door aandeelhouders van niet-beursvennootschappen. Dit geldt uitdrukkelijk niet voor onze analyse in paragraaf 6 en 7, omdat die analyse specifiek is toegespitst op koersschade geleden door beleggers in beursvennootschappen. Een andere opmerking van terminologische aard is nog dat wij in het vervolg van dit artikel niet steeds zullen refereren aan de wanprestatie of O.D. van een derde jegens de vennootschap, maar simpelweg zullen spreken van de 'normschending' van een derde jegens de vennootschap.

\section{Het onderscheid tussen directe en afgeleide schade}

Een belangrijk onderscheid dat gemaakt dient te worden, is het onderscheid tussen enerzijds directe schade en anderzijds afgeleide schade. Door Kroeze - die daarin is gevolgd door Assink 
- wordt afgeleide schade opgevat als een feitelijk, beschrijvend begrip. ${ }^{3}$ Kroeze verstaat onder afgeleide schade de schade die een aandeelhouder lijdt door waardevermindering van zijn aandelen, wanneer en voor zover deze waardevermindering het gevolg is van schade die aan de vennootschap is toegebracht. ${ }^{4}$ In deze opvatting wordt het afgeleide-schadebegrip bepaald door de feitelijke (en objectief vast te stellen) vorm waarin de schade wordt geleden, namelijk aan de aandelen via het vermogen van de vennootschap. De toedracht van de schade maakt in deze opvatting dus geen onderdeel uit van de definitie van het afgeleide-schadebegrip. De schade van de vennootschap hoeft met andere woorden niet noodzakelijkerwijs het gevolg te zijn van de normschending van een derde jegens de vennootschap om voor de daarmee corresponderende waardedaling van de aandelen van 'afgeleide schade' te kunnen spreken. ${ }^{5}$ Daarmee wordt een scheiding aangebracht tussen gevallen van afgeleide schade die wel onder de hierna te bespreken Poot/ABP-doctrine vallen, omdat deze schade is veroorzaakt door de normschending van een derde jegens de vennootschap, en gevallen van afgeleide schade die niet onder deze doctrine vallen. In de opvatting van Kroeze en Assink heeft de Poot/ABPdoctrine weliswaar altijd betrekking op afgeleide schade, maar vallen niet alle gevallen van afgeleide schade onder de Poot/ABP-doctrine. ${ }^{6}$ Iets anders is dat afgeleide schade als beschrijvend begrip eigenlijk pas juridisch relevant is op het moment dat een derde, waaronder ook moet worden verstaan een bestuurder van de vennootschap, schade toebrengt aan de vennootschap met als gevolg dat ook de aandeelhouders schade lijden.

In tegenstelling tot afgeleide schade loopt directe schade - ook wel rechtstreekse schade genoemd - niet via het vermogen van de vennootschap. Stel dat een vennootschap haar financiële positie in haar financiële verslaggeving te rooskleurig voorstelt. ${ }^{7}$ Toekomstige en

\footnotetext{
${ }^{3}$ M.J. Kroeze, Afgeleide schade en afgeleide actie (diss. Utrecht; IVOR nr. 45), Deventer: Kluwer 2004, p. 11 en 17-18 en B.F. Assink, Vraagtekens rond afgeleide schade, in: P.J. van der Kost, R. Abma \& G.T.M.J. Raaijmakers (red.), Handboek onderneming en aandeelhouder (O\&R nr. 69), Deventer: Kluwer 2012, p. 312.

${ }^{4}$ Kroeze 2004, p. 17-18.

5 In de literatuur wordt ook wel een enger afgeleide-schadebegrip bepleit. In deze benadering maakt de normschending van de derde jegens de vennootschap onderdeel uit van het afgeleide-schadebegrip. Steun voor deze opvatting zou op het eerste gezicht kunnen worden gevonden in het arrest HR 12 oktober 2018, ECLI:NL:HR:2018:1899, JOR 2019/30 m.nt. J. de Bie Leuveling Tjeenk (Potplantenkwekerij). Deze opvatting is volgens ons echter niet zo makkelijk te verenigen met het reguliere onrechtmatigedaadsrecht. Zo wordt feitelijk nadeel dat iemand heeft geleden niet pas als 'schade' aangemerkt, als aan alle overige eisen van aansprakelijkheid uit onrechtmatige daad is voldaan. Tevens gaat deze opvatting eraan voorbij dat de Hoge Raad het begrip 'afgeleide schade' in r.o. 3.5.2 van het zojuist genoemde Potplantenkwekerij-arrest weliswaar niet expliciet noemt, maar dat de daar genoemde schadeposten bij uitstek verschijningsvormen zijn van afgeleide schade, namelijk schade in de vorm van gemiste dividenduitkeringen of een lagere waarde van de aandelen, wanneer en voor zover deze schadeposten het gevolg zijn van schade die aan de vennootschap is toegebracht. Vgl. voor deze discussie A.J.P. Schild \& J.M. de Jongh, Timmerman en afgeleide schade, in: H.J. de Kluiver (red.), De rol van de rechter in het ondernemingsrecht. Beschouwingen bij het afscheid van prof. mr. L. Timmerman als advocaatgeneraal bij de Hoge Raad, Zutphen: Uitgeverij Parijs 2020, p. 108-111. Zie voor een kraakheldere analyse van het Potplantenkwekerij-arrest het commentaar van B.F. Assink bij HR 12 oktober 2018, ECLI:NL:HR:2018:1899, Ondernemingsrecht 2019/127.

${ }^{6}$ Zie B.F. Assink in zijn commentaar bij HR 12 oktober 2018, ECLI:NL:HR:2018:1899, Ondernemingsrecht 2019/127. Zie in dit verband ook de zeer lezenswaardige conclusie van A-G Hartlief van 11 september 2020, ECLI:NL:PHR:2020:960 (X/Rabobank), par. 3.1-3.31, waar hij in zijn algemene beschouwingen over afgeleide schade en de Poot/ABP-doctrine de opvatting van Kroeze respectievelijk Assink lijkt te volgen.

${ }^{7}$ Zie over de aansprakelijkheid die aan de orde is als een vennootschap haar financiële positie in haar financiële verslaggeving te rooskleurig voorstelt uitgebreid A.C.W. Pijls, Civielrechtelijke aansprakelijkheid voor
} 
zittende aandeelhouders (en overigens ook obligatiehouders) en toekomstige en zittende beleggers in financiële instrumenten die van de door deze vennootschap uitgegeven effecten zijn afgeleid, kunnen worden misleid op het moment dat zij hun beleggingsbeslissing direct of indirect op deze misleidende financiële verslaggeving baseren. De schade die zij bij het naar buiten komen van de misleiding (definitief) lijden, wordt rechtstreeks geleden en loopt niet via het vermogen van de vennootschap. Hierbij moet worden bedacht dat als gevolg van de misleiding de vermogenspositie van de vennootschap weliswaar rooskleuriger wordt voorgesteld dan zij in werkelijkheid is, maar dat het vennootschapsvermogen hierdoor op zichzelf niet - althans niet direct - wordt geraakt. ${ }^{8}$

Specifiek bij beursvennootschappen kan daarnaast onderscheid worden gemaakt tussen enerzijds afgeleide schade en anderzijds een soort toekomstvariant daarvan. ${ }^{9}$ Als een bestuurder van de vennootschap fraude pleegt (denk aan een greep uit de kas), zal de schade van de vennootschap (althans in ieder geval een deel daarvan) meteen intreden, maar is pas sprake van afgeleide schade van de aandeelhouder op het moment dat de fraude bekend wordt en de aandelenkoers als gevolg daarvan daalt. ${ }^{10}$ In een dergelijk geval is dus eerst sprake van schade van de vennootschap en pas bij het uitkomen van de fraude van afgeleide schade van de aandeelhouder. Een en ander ligt een stuk genuanceerder in de situatie waarin het bestuur van de vennootschap een verkeerde beleidsbeslissing neemt. Bij het bekend worden van de verkeerde beleidsbeslissing - bewust abstraheren wij hier van de vraag of de bestuurder of bestuurders jegens de vennootschap aansprakelijk zijn voor de gevolgen van deze beslissingzal de aandelenkoers direct dalen, maar dit hoeft op zichzelf niet te betekenen dat ook het vennootschapsvermogen door deze beslissing direct wordt geraakt. De koersdaling na het uitkomen van de beleidsbeslissing representeert de verwachting die de aandelenmarkt heeft ten aanzien van toekomstige vermogensverliezen die de vennootschap (als gevolg van deze beslissing) zal lijden en die dus meteen in de aandelenkoers worden ingeprijsd. In een dergelijk geval is dus al sprake van koersschade van de aandeelhouder voordat de vermogensschade zich bij de vennootschap heeft gematerialiseerd. De vraag die zich meteen aandient, is of deze koersschade van de aandeelhouder kan worden aangemerkt als 'afgeleid'. Zolang de schade bij de vennootschap zich nog niet heeft gematerialiseerd, zouden wij deze vraag ontkennend willen beantwoorden. Zolang de vennootschap nog geen schade heeft geleden, loopt de koersschade van de aandeelhouder namelijk niet via het vermogen van de vennootschap. Zodra echter de schade bij de vennootschap intreedt (dit kan al het geval zijn als het bestuur van de vennootschap in het kader van haar financiële verslaggeving besluit tot het opnemen van een voorziening), 'verschiet' de reeds in de aandelenkoers ingeprijsde toekomstige afgeleide

misleidende financiële verslaggeving, in: J.B.S. Hijink e.a. (red.), Handboek jaarrekeningenrecht (VDHI nr. 164), Deventer: Wolters Kluwer 2020, hoofdstuk 49.

${ }^{8}$ Een vrij recent voorbeeld van een aandeelhouder met directe schade deed zich voor in de zaak Licorne Holding (HR 28 september 2018, ECLI:NL:HR:2018:1811, Ondernemingsrecht 2019/30 m.nt. B. Kemp), al ging het in deze zaak niet om koersschade geleden door een aandeelhouder in een beursvennootschap.

${ }^{9}$ Een van ons schreef al eens over dit onderscheid, zie A.C.W. Pijls, Een bijzonder type gevolgschade bij misleidende berichtgeving op de beurs, in: Piet Sanders: een honderdjarige vernieuwer, Den Haag: Boom Juridische uitgevers 2012, par. 2. Zie in dit verband ook B.F. Assink, Slagter. Compendium ondernemingsrecht, Deventer: Kluwer 2013, p. 253.

${ }^{10}$ Op het moment dat de fraude bekend wordt, zal de aandeelhouder naast afgeleide schade vaak ook nog verdere gevolgschade lijden, maar dat laten wij hier buiten beschouwing. Zie over die gevolgschade Pijls 2012, par. 1. 
schade 'van kleur' en kan de reeds ingetreden koersdaling worden aangemerkt als 'echte' afgeleide schade.

Bij het voorgaande is nog van belang om op te merken dat op het moment dat het daadwerkelijk intreden van de schade bij de vennootschap bekend wordt, in beginsel geen nieuwe koersdaling zal intreden (dit ligt uiteraard anders als de schade van de vennootschap groter is dan aanvankelijk door de markt werd verwacht en in de aandelenkoers werd ingeprijsd). Uit het uitblijven van een dergelijke koersdaling mag echter niet de conclusie worden getrokken dat de aandeelhouder geen afgeleide schade lijdt. De aandeelhouder leed namelijk al koersschade toen de verkeerde beleidsbeslissing bekend werd en de gevolgen daarvan in de aandelenkoers werden ingeprijsd, maar pas bij het daadwerkelijk intreden van de schade bij de vennootschap loopt de daarmee corresponderende koersschade van de aandeelhouder via het vermogen van de vennootschap. Pas vanaf dat moment kan deze koersschade worden aangemerkt als 'afgeleid'. ${ }^{11}$

Specifiek bij beursvennootschappen moet dus een onderscheid worden gemaakt tussen enerzijds schade van de vennootschap die zich al heeft gematerialiseerd en daarmee corresponderende afgeleide schade van de aandeelhouder, en anderzijds schade die de vennootschap in de toekomst - naar verwachting - zal lijden en die zich nog niet heeft gematerialiseerd, maar die al wel in de aandelenkoers is ingeprijsd en in zoverre als een soort toekomstvariant van 'gewone' afgeleide schade is te beschouwen. Voor het vervolg merken wij op dat als wij hierna spreken van 'afgeleide schade', wij daarmee bedoelen 'gewone' afgeleide schade en niet de zojuist bedoelde toekomstvariant. De rechtvaardiging voor deze afbakening is erin gelegen dat als de aandeelhouder al een vordering instelt tot vergoeding van zijn afgeleide schade, daar in de praktijk altijd enige tijd overheen zal gaan. In veruit de meeste gevallen zal het dan zo zijn dat inmiddels ook sprake is van - in ieder geval enige gematerialiseerde schade bij de vennootschap.

\title{
3 De Poot/ABP-doctrine en de ratio daarvan
}

De kern (en hoofdregel) van het Poot/ABP-arrest luidt als volgt: ${ }^{12}$

\begin{abstract}
'Naamloze vennootschappen en besloten vennootschappen met beperkte aansprakelijkheid zijn rechtspersonen die zelfstandig, als dragers van eigen rechten en verplichtingen, aan het rechtsverkeer deelnemen (...). Het vermogen van een vennootschap is afgescheiden van dat van zijn aandeelhouders. Indien aan een vennootschap door een derde vermogensschade wordt toegebracht door het niet behoorlijk nakomen van contractuele verplichtingen jegens de vennootschap of door gedragingen die tegenover de vennootschap onrechtmatig zijn, heeft alleen de

\footnotetext{
${ }^{11}$ Een ander scenario dat zich in de praktijk kan voordoen, is dat de schade die de vennootschap als gevolg van de verkeerde beleidsbeslissing lijdt, kleiner is dan aanvankelijk door de markt werd verwacht en in de aandelenkoers werd ingeprijsd. In dat geval zal bij het bekend worden van de schade van de vennootschap een koersstijging plaatsvinden. Ook uit deze koersstijging mag vanzelfsprekend niet de conclusie worden getrokken dat de aandeelhouder geen afgeleide schade lijdt.

${ }^{12}$ HR 2 december 1994, ECLI:NL:HR:1994:ZC1564, NJ 1995/288 m.nt. J.M.M. Maeijer (Poot/ABP), r.o. 3.4.1.
} 
vennootschap het recht uit dien hoofde van de derde vergoeding van deze aan haar toegebrachte schade te vorderen. Die vermogensschade van de vennootschap zal, zolang zij niet is vergoed, een vermindering van de waarde van de aandelen in de vennootschap meebrengen. In beginsel kunnen de aandeelhouders echter op grond van dit (aanvankelijk) voor hen ontstane nadeel niet een eigen vordering tot schadevergoeding tegen de bedoelde derde geldend maken.'

De Poot/ABP-doctrine, die er in essentie op neerkomt dat afgeleide schade van de aandeelhouder die het gevolg is van de normschending van een derde jegens de vennootschap (en daardoor veroorzaakte schade aan het vennootschapsvermogen) niet rechtstreeks voor vergoeding in aanmerking komt, kan met verschillende argumenten worden gerechtvaardigd. Naast het bekende argument van rechtspersoonlijkheid van de vennootschap en de daaraan gerelateerde afwezigheid van een tot schadevergoeding strekkende rechtsverhouding tussen de aandeelhouder en de derde, worden in de literatuur verschillende doelmatigheidsargumenten c.q. beleidsmatige afwegingen genoemd, waarvan wij hier de belangrijkste vier parafraseren: ${ }^{13}$ 1) Rechtstreekse schadevergoeding aan aandeelhouders doet afbreuk aan de geldende rangorde tussen aandeelhouders en schuldeisers. Aandeelhouders zijn verschaffers van risicodragend kapitaal en zouden daarom niet een preferente positie moeten kunnen innemen ten opzichte van schuldeisers. ${ }^{14}$

2) Rechtstreekse schadevergoeding kan inbreuk maken op de rangorde tussen aandeelhouders onderling.

3) Rechtstreekse schadevergoeding kan leiden tot het door de derde betalen van dubbele schadevergoeding en tot het door de aandeelhouder ontvangen van dubbele schadevergoeding.

4) Het principieel afwijzen van de vergoeding van afgeleide schade van de aandeelhouder voorkomt een 'cascade' aan procedures van individuele aandeelhouders.

Het in paragraaf 2 uiteengezette onderscheid tussen directe en afgeleide schade is van belang voor het antwoord op de vraag of een individuele aandeelhouder de schadeveroorzakende derde - met succes - rechtstreeks kan aanspreken tot vergoeding van door hem geleden koersschade. Als sprake is van directe schade, is de Poot/ABP-doctrine hoe dan ook niet van toepassing en kan de individuele aandeelhouder zijn koersschade rechtstreeks op de derde verhalen (ervan uitgaande dat in de verhouding aandeelhouder versus derde aan alle aansprakelijkheidsvereisten van O.D. is voldaan). Loopt de koersschade van de aandeelhouder daarentegen via het vermogen van de vennootschap en is dus sprake van afgeleide schade, dan staat de Poot/ABP-doctrine in beginsel aan rechtstreekse vergoeding in de weg, als de derde jegens de vennootschap een norm heeft geschonden en de vennootschap uit dien hoofde een vordering(srecht) heeft op de derde. Er bestaat echter een uitzondering op deze hoofregel en die bespreken wij in paragraaf 5 .

${ }^{13}$ Zie Kroeze 2004, p. 37-39; Kroeze 2012, p. 33; Assink 2012, p. 307-308. Zie ook W.J. Oostwouder, Actualiteiten 'afgeleide schade'. What's in the name?, O\&F 2018, afl. 4, p. 7-8.

${ }^{14} \mathrm{Vgl}$. art. 2:23b lid $1 \mathrm{BW}$. 


\section{Wat indien de vennootschap zelf wordt aangesproken tot vergoeding van afgeleide schade?}

Wordt de afgeleide schade van de aandeelhouder beweerdelijk veroorzaakt door een of meer bestuurders van de vennootschap en/of door een of meer hooggeplaatste managers, dan is een interessante variant op de casus waarin de aandeelhouder van de bestuurder(s) en/of manager(s) vergoeding vordert van zijn afgeleide schade, het geval waarin de aandeelhouder van de vennootschap vergoeding vordert van zijn afgeleide schade. De aandeelhouder zal zich dan op het standpunt stellen dat de handelingen van de bestuurder(s) en/of manager(s) aan de vennootschap kunnen worden toegerekend. ${ }^{15}$ Ondanks het feit dat de Poot/ABP-doctrine niet op deze situatie van toepassing is, denken wij dat haar ratio ook in dat geval van zich doet spreken. In de WCAM-beschikking inzake de Fortis-schikking overweegt het gerechtshof Amsterdam over koersverlies dat de aandeelhouder stelt te hebben geleden als gevolg van verkeerde beleidskeuzes van de vennootschap als volgt: ${ }^{16}$

'Voor een belegger is het in beginsel niet mogelijk de vennootschap waarvan hij aandelen houdt met succes uit onrechtmatige daad aansprakelijk te houden voor geleden koersverlies als gevolg van de beleidskeuzes die deze vennootschap heeft gemaakt (...). Een belegger zal in de regel ervoor kiezen te beleggen in bedrijven waarvan hij de verwachting heeft dat deze financiële meerwaarde zullen creëren, om in die winst en waardeontwikkeling als aandeelhouder te kunnen delen. De keerzijde is uiteraard dat een aandeelhouder eveneens deelt in een negatieve waardeontwikkeling, ook die het gevolg is van de beleidskeuzes die de betreffende vennootschap heeft gemaakt. De mogelijkheid dat een vennootschap als gevolg van het gevoerde beleid waardeverlies lijdt en daardoor koersverlies ontstaat, behoort bij uitstek tot het risico dat een belegger in aandelen loopt als (de meest) achtergestelde schuldeiser van een vennootschap. Aandeelhouders kunnen dergelijk koersverlies in beginsel niet op de vennootschap verhalen. Dat staat op gespannen voet met de rangorde die schuldeisers onderling ten opzichte van de vennootschap innemen. Aandeelhouders worden anderszins beschermd, doordat hen juridische middelen ten dienste staan om invloed op het beleid van de vennootschap uit te oefenen of dat eventueel ter toetsing voor te leggen aan de rechter.'

Met bovenstaande overwegingen zijn wij het van harte eens. Hoewel het hof niet expliciet refereert aan de Poot/ABP-doctrine, klinken in zijn overwegingen wel aan deze doctrine ten grondslag liggende argumenten door, zoals het verschil in rangorde tussen aandeelhouders en schuldeisers.

\footnotetext{
${ }^{15}$ HR 6 juni 1979, ECLI:NL:HR:1979:AH8595, NJ 1980/34 m.nt. C.J.H. Brunner (Kleuterschool Babbel).

${ }^{16}$ Hof Amsterdam 13 juli 2018, ECLI:NL:GHAMS:2018:2422 (WCAM-procedure Fortis-schikking), r.o. 5.32 e.v.
} 


\section{Uitzondering bij schending van een specifieke zorgvuldigheidsnorm jegens de aandeelhouder}

Er kan sprake zijn van een uitzondering op de hoofdregel van het Poot/ABP-arrest, als de aandeelhouder aannemelijk maakt dat de derde jegens hem een specifieke zorgvuldigheidsnorm heeft geschonden. ${ }^{17}$ Schending van zo'n specifieke zorgvuldigheidsnorm is een noodzakelijke voorwaarde waaraan moet zijn voldaan, wil de afgeleide schade van de aandeelhouder eventueel voor vergoeding in aanmerking komen. Komt schending van zo'n specifieke zorgvuldigheidsnorm inderdaad in rechte vast te staan, dan is in onze visie echter nog steeds sprake van afgeleide schade. Door schending van zo'n specifieke zorgvuldigheidsnorm 'promoveert' de afgeleide schade niet ineens tot rechtstreekse schade. ${ }^{18}$ Uit het arrest Tuin Beheer/Houthoff blijkt dat van schending van een specifieke zorgvuldigheidsnorm onder meer sprake kan zijn indien de derde opzettelijk schade toebrengt aan de vennootschap met het oogmerk een of meer aandeelhouders te benadelen. ${ }^{19}$ Is de aangesproken derde een bestuurder, dan is voor het aannemen van schending van een specifieke zorgvuldigheidsnorm in de verhouding bestuurder versus individuele aandeelhouder vereist dat de bestuurder een persoonlijk ernstig verwijt kan worden gemaakt. ${ }^{20}$ Zo'n persoonlijk ernstig verwijt wordt in beginsel aangenomen als de bestuurder in strijd heeft gehandeld met een statutaire bepaling die de desbetreffende individuele aandeelhouder beoogt te beschermen. ${ }^{21}$

Uit de door de Hoge Raad gewezen arresten op het terrein van afgeleide schade blijkt niet of er naast de schending van een specifieke zorgvuldigheidsnorm jegens de aandeelhouder, andere, bijkomende voorwaarden zijn waaraan moet zijn voldaan om de afgeleide schade van de aandeelhouder rechtstreeks voor vergoeding in aanmerking te laten komen. Door onder meer Timmerman en Oostwouder wordt het definitief zijn van de schade van de vennootschap als harde voorwaarde beschouwd voor het rechtstreeks vergoeden van de afgeleide schade van de aandeelhouder. ${ }^{22}$ Voor Assink is het al dan niet definitieve karakter van de afgeleide schade

\footnotetext{
${ }^{17}$ HR 14 juni 2001, ECLI:NL:HR:2001:AB2443, NJ 2001/573 m.nt. J.M.M. Maeijer (Chipshol); HR 16 februari 2007, ECLI:NL:HR:2007:AZ0419, NJ 2007/256 m.nt. J.M.M. Maeijer (Tuin Beheer/Houthoff), r.o. 3.3 sub c; HR 2 november 2007, ECLI:NL:HR:2007:BB3671, NJ 2008/5 m.nt. J.M.M. Maeijer (Kessock), r.o. 3.4.

${ }^{18}$ Kroeze 2012, p. 29-32. Anders A.J.P. Schild, Aandeelhouders, schuldeisers en afgeleide schade, Bb 2007, afl. 17, p. 191-199.

${ }^{19}$ HR 16 februari 2007, ECLI:NL:HR:2007:AZ0419, NJ 2007/256 m.nt. J.M.M. Maeijer (Tuin Beheer/Houthoff), r.o. 3.5. De Hoge Raad lijkt hier een koppeling te maken tussen de aard van de normschending (schending van een specifieke zorgvuldigheidsnorm) en de mate van verwijtbaarheid (opzet tot benadeling). Kritisch hierover: Schild \& De Jongh 2020, p. 111. Wij lezen dit arrest echter niet aldus dat opzet tot benadeling van de aandeelhouder een noodzakelijke voorwaarde is (waaraan dus altijd moet zijn voldaan) om in de verhouding derde versus aandeelhouder de schending van een specifieke zorgvuldigheidsnorm aan te nemen.

${ }^{20}$ HR 20 juni 2008, ECLI:NL:HR:2008:BC4959, NJ 2009/21 m.nt. H.J. Snijders (Willemsen/NOM). Zie ook conclusie A-G Timmerman, ECLI:NL:PHR:2010:BK4927, par. 3.4 .2 bij HR 22 januari 2010, ECLI:NL:HR:2010:BK4927, RvdW 2010/188.

${ }^{21}$ Idem.

${ }^{22}$ Zie L. Timmerman, Kan een aandeelhouder of vennootschapsschuldeiser afgeleide schade vorderen?, TVVS 1998/50, p. 99 respectievelijk Oostwouder 2018, p. 11-12. Vgl. conclusie A-G Hartkamp, ECLI:NL:PHR:2001:AB2443, par. 10 bij HR 14 juni 2001, ECLI:NL:HR:2001:AB2443, NJ 2001/573 m.nt. J.M.M. Maeijer (Chipshol) en Hof Arnhem-Leeuwarden 12 juni 2018, ECLI:NL:GHARL:2018:5411, JOR 2018/207 m.nt. P.H.M. Broere (Baranov), r.o. 6.36.
} 
van de aandeelhouder (het definitief zijn van de schade van de vennootschap betekent per definitie dat ook de afgeleide schade van de aandeelhouder definitief is; andersom geldt dit niet) een 'dominant' gezichtspunt bij de beoordeling of deze afgeleide schade al dan niet rechtstreeks voor vergoeding in aanmerking komt. ${ }^{23}$ Andere gezichtspunten die Assink voor deze beoordeling van belang vindt, zijn: ${ }^{24}$

1) de mate waarin de aandeelhouder via het aanwenden van zijn vennootschapsrechtelijke zeggenschapsrechten in staat moet worden geacht de vennootschap te bewegen de derde aansprakelijk te stellen, indien het bestuur hier niet toe overgaat; ${ }^{25}$

2) de gevolgen van toewijzing van de vordering van de aandeelhouder voor de verhaalspositie van crediteuren van de vennootschap;

3) de gevolgen van toewijzing van de vordering van de aandeelhouder voor de positie van zijn medeaandeelhouders;

4) het aantal tot vergoeding van afgeleide schade strekkende rechtsvorderingen dat door individuele aandeelhouders tegen de derde is of zal worden ingesteld (gelet op de mogelijke chaotische gevolgen daarvan);

5) de mate waarin de aangesproken derde gedwongen zou kunnen worden de schade van de aandeelhouder dubbel te vergoeden, en de kans dat de aandeelhouder zodoende meer vergoeding zou ontvangen dan zijn schade beloopt; en

6) de aan- of afwezigheid van opzet tot benadeling van de aandeelhouder bij de derde.

Deze gezichtspunten van Assink komen voor een belangrijk deel overeen met de door Kroeze in zijn doorkruisingsleer genoemde doelmatigheids- en rechtvaardigheidsargumenten. ${ }^{26}$ Gelet op de in paragraaf 3 genoemde doelmatigheidsargumenten c.q. beleidsmatige afwegingen die aan de Poot/ABP-doctrine ten grondslag liggen en gelet op bovenstaande gezichtspunten van Assink, stellen wij ons in ieder geval op het standpunt dat de aandeelhouder jegens wie een specifieke zorgvuldigheidsnorm is geschonden, niet per definitie recht heeft op schadevergoeding. Wij interpreteren de uitzondering op de hoofregel uit het Poot/ABP-arrest aldus dat deze aandeelhouder pas recht heeft op schadevergoeding, als er in het concrete geval geen voldoende zwaarwegende argumenten (meer) zijn die zich tegen vergoeding verzetten. ${ }^{27}$

\section{Intermezzo: de optiemarkt en de werking van opties}

Naast handel in normale aandelen bestaat ook een levendige handel in stock options. Zo kunnen via Euronext Amsterdam opties op aandelen van beursvennootschappen worden verhandeld. De koper van een optie heeft het recht om op een bepaald moment of gedurende een zekere periode (bijvoorbeeld een week of maand) een bepaalde hoeveelheid aandelen te kopen of

\footnotetext{
${ }^{23}$ Zie Assink 2013, p. 267. Assink vindt het al dan niet definitieve karakter van de afgeleide schade van de aandeelhouder weliswaar een 'dominant' gezichtspunt, maar hij gaat niet zo ver dat hij het definitief zijn van de afgeleide schade van de aandeelhouder als voorwaarde stelt waaraan in ieder geval moet zijn voldaan om deze rechtstreeks voor vergoeding in aanmerking te laten komen. Het hanteren van een dergelijke eis vindt hij 'te categorisch', aldus Assink 2013, p. 267, voetnoot 188.

${ }^{24}$ Zie Assink 2012, p. 337-338 en Assink 2013, p. 266.

${ }^{25}$ Hierbij past wel de kanttekening dat het door de aandeelhouder aanwenden van vennootschapsrechtelijke zeggenschapsrechten bij een beursvennootschap in de regel weinig effect zal hebben.

${ }^{26}$ Kroeze 2004, p. 66-67.

${ }^{27}$ Begrijpen wij hem goed, dan is dit ook de interpretatie van A-G Hartlief in zijn conclusie van 11 september 2020, ECLI:NL:PHR:2020:960 (X/Rabobank), par. 3.25-3.30.
} 
verkopen voor een in de optieovereenkomst vastgestelde uitoefenprijs. ${ }^{28}$ De dag waarop de optie afloopt, wordt ook wel de expiration date genoemd. In dit verband is van belang het onderscheid tussen zogenoemde 'American style'- en 'European style'-opties. Bij American style-opties heeft de optienemer tot aan de expiration date de mogelijkheid de optie uit te oefenen. Bij European style-opties kan de optienemer de optie slechts uitoefenen op de expiration date en is eerdere uitoefening van de optie niet mogelijk. Al naar gelang de style van de optie kan de expiration date dus de laatst mogelijke uitoefendatum van de optie zijn, dan wel de enige uitoefendatum. Indien een optiebelegger een zogenoemde 'call-optie' afsluit, behelst deze optie het recht om op een bepaald moment of gedurende een zekere periode een bepaald aantal aandelen van de verkoper/schrijver van de optie te kopen tegen een in de optieovereenkomst afgesproken uitoefenprijs, ook wel de strike price genoemd. Omwille van de omvang van dit artikel beperken wij onze analyse tot dergelijke call-opties.

De optienemer en -schrijver komen in het optiecontract de voorwaarden overeen waaronder de optienemer het recht verkrijgt de desbetreffende aandelen te kopen. Volgens dit optiecontract zijn - bij uitoefening van de optie - rechten van de optienemer verplichtingen van de optieschrijver. In de voorwaarden van het optiecontract staan verder onder andere de expiration date en uitoefenprijs van de optie en de prijs die de optienemer aan de optieschrijver dient te betalen voor het verkrijgen van de optie. ${ }^{29}$ De prijs die voor de optie wordt betaald, wordt ook wel de premie genoemd en weerspiegelt de waarde ('value') van de optie. De value van een optie bestaat naast de intrinsieke waarde van de optie ${ }^{30}$ uit de tijd- en verwachtingswaarde. ${ }^{31}$ Indien de beurskoers van het onderliggende aandeel op de expiration date boven de uitoefenprijs ligt, zal het in de regel zo zijn dat de nemer van de call-optie zijn optie uitoefent. Zijn brutowinst bestaat dan uit het verschil tussen de beurskoers op de expiration date en de in de call-optie gehanteerde uitoefenprijs. Om echter de nettowinst te berekenen zal de (toekomstige waarde van de) betaalde premie hierop in mindering moeten worden gebracht. ${ }^{32}$ Verder is van belang dat in de praktijk de afwikkeling van het optiecontract na uitoefening van de optie vaak plaatsvindt in de vorm van cash settlement, ook wel 'mark-to-market' genoemd. Bij cash settlement vindt - in tegenstelling tot afwikkeling in de vorm van physical delivery geen daadwerkelijke levering van het aandeel plaats en wordt tussen de optienemer en optieschrijver slechts financieel afgerekend.

\footnotetext{
${ }^{28}$ Asser/De Serière 2-IV 2018/68.

${ }^{29}$ R.L. McDonald, Derivatives markets (derde druk), Upper Saddle River (NJ): Pearson Education 2013, p. 3536. Bij werknemersopties wordt over het algemeen geen prijs betaald voor het verkrijgen van de optie, nu de optie deel uitmaakt van de beloning. Bij uitoefening van de optie zal voor het verkrijgen van de aandelen wel de uitoefenprijs moeten worden betaald.

${ }^{30}$ Stel, er is een call-optie gekocht op aandelen X met een uitoefenprijs van EUR 45. Indien de koers van aandeel X op dat moment EUR 46 bedraagt, heeft de optie een intrinsieke waarde van EUR 1, namelijk het verschil tussen de uitoefenprijs van de optie en de actuele aandelenkoers. Bedraagt de aandelenkoers echter EUR 44, dan heeft de optie op dat moment geen intrinsieke waarde.

${ }^{31}$ De tijd- en verwachtingswaarde weerspiegelen de onzekerheid in de koersontwikkeling van het onderliggende aandeel tot het aflopen van de optie op de expiration date.

${ }^{32}$ Voor het bepalen van de nettowinst laten wij overige transactiekosten hier gemakshalve buiten beschouwing. Zie ook McDonald 2013, p. 36-37.
} 
Het bovenstaande kan eenvoudig inzichtelijk worden gemaakt aan de hand van een getallenvoorbeeld. In dit getallenvoorbeeld gaan wij uit van een European style-optie (de uitoefendatum valt dus per definitie samen met de expiration date). ${ }^{33}$ Stel dat een optiebelegger een call-optie koopt met een uitoefenprijs van EUR 50 en een looptijd van drie maanden tot de expiration date. De prijs van de optie is momenteel EUR 2 en de koers van het onderliggende aandeel $\mathrm{X}$ is op het moment van het afsluiten van de optie EUR 47. In de praktijk heeft een optiecontract meestal betrekking op 100 aandelen, zodat de totale investering van de optiebelegger EUR 200 is. Als de koers van het onderliggende aandeel X op de expiration date lager is dan de uitoefenprijs van EUR 50, is de optie out of the money en zal de belegger zijn call-optie niet uitoefenen. De belegger verliest dan zijn initiële investering van EUR 200. Noteert de koers van het onderliggende aandeel op de expiration date precies EUR 50, dan is de call-optie weliswaar at the money, maar ook dan zal de belegger zijn optie waarschijnlijk niet uitoefenen. Is de koers van het onderliggende aandeel op de expiration date echter hoger dan de uitoefenprijs van EUR 50, dan is de optie in the money. Alleen in het laatste geval is het voor de belegger interessant de call-optie uit te oefenen. De nettowinst van de belegger kan dan evenwel nog steeds negatief zijn, hetgeen het geval is als het bedrag waarmee de optie in the money is lager is dan de voor de optie betaalde premie. Zoals blijkt uit tabel 1 doet een dergelijke situatie zich bijvoorbeeld voor als de koers van het onderliggende aandeel op de expiration date EUR 51 bedraagt. Pas bij een koers van het onderliggende aandeel op de expiration date hoger dan EUR 52 is sprake van een op de optie te behalen positief rendement. Is de call-optie op de expiration date in the money, dan is het voor de belegger echter hoe dan ook lucratief de optie uit te oefenen, aangezien de investering van de betaalde premie dan in ieder geval gedeeltelijk kan worden terugverdiend met de op de optie te behalen winst. ${ }^{34}$ Tabel 1 geeft een overzicht van een aantal mogelijke uitkomsten bij verschillende beurskoersen van het onderliggende aandeel.

Tabel 1. Beleggingsresultaat call-optie bij verschillende beurskoersen van het onderliggende aandeel

\begin{tabular}{llll}
\hline $\begin{array}{l}\text { Koers } \\
\text { onderliggend } \\
\text { aandeel X op } \\
\text { expiration }\end{array}$ & $\begin{array}{l}\text { Brutowinst } \\
\text { op de call- } \\
\text { optie }\end{array}$ & $\begin{array}{l}\text { Betaalde } \\
\text { premie } \\
\text { voor }\end{array}$ & $\begin{array}{l}\text { Nettowinst } \\
\text { op de call- } \\
\text { call- } \\
\text { optie }\end{array}$ \\
\hline $\mathbf{4 9}$ & & 2 & -2 \\
$\mathbf{5 0}$ & 0 & 2 & -2 \\
$\mathbf{5 1}$ & 0 & 2 & -1 \\
$\mathbf{5 2}$ & 1 & 2 & 0 \\
$\mathbf{5 3}$ & 2 & 2 & 1 \\
$\mathbf{5 4}$ & 3 & 2 & 2 \\
\hline
\end{tabular}

\footnotetext{
${ }^{33}$ Ons uitgangspunt van een European style-optie heeft overigens geen gevolgen voor de berekening van de op de optie te behalen brutowinst.

${ }^{34}$ J.C. Hull, Options, futures and other derivatives (negende druk), Upper Saddle River (NJ): Pearson Education 2015, p. 214.
} 

optiebeleggers

Alvorens de vraag te beantwoorden of de Poot/ABP-doctrine ook van toepassing is op koersgerelateerde schade geleden door optiebeleggers, is het van belang te benadrukken dat de rechtsverhouding tussen de optiebelegger en de vennootschap wezenlijk verschilt van de rechtsverhouding tussen de aandeelhouder en de vennootschap. Zo kan een optiebelegger niet worden aangemerkt als verschaffer van risicodragend kapitaal aan de vennootschap. Dit betekent onder meer dat hij bij vereffening na ontbinding van de rechtspersoon geen uitkering ontvangt uit een eventueel liquidatieoverschot (zie art. 2:23b lid $1 \mathrm{BW}$ ). Ook is van belang dat de juridische positie van de optiebelegger primair wordt bepaald door de voorwaarden waaronder de desbetreffende optie is aangegaan, zoals vastgelegd in het optiecontract. Voor de vennootschap is de optie louter een afgeleid financieel instrument, hetgeen betekent dat de houder ervan geen invloed kan uitoefenen op het beleid van de vennootschap. Pas door uitoefening van de optie (en dan alleen bij afwikkeling in de vorm van physical delivery) wordt het aandeel verkregen en kunnen - op grond van het aandeelhouderschap zeggenschapsrechten jegens de vennootschap worden uitgeoefend.

Het voorgaande laat onverlet dat de optiebelegger koersgerelateerde schade kan lijden als gevolg van (1) misleidende berichtgeving van de vennootschap, of (2) de normschending van een derde jegens de vennootschap. In het eerste geval lijdt bijvoorbeeld de koper van een calloptie schade als aan de volgende voorwaarden is voldaan:

1) De call-optie is in het tijdvak van de misleiding gekocht.

2) De voor de optie betaalde premie en de uitoefenprijs zijn door de misleiding beïnvloed.

3) De optie is als gevolg van het bekend worden van de misleiding (en de daardoor veroorzaakte koersdaling van het onderliggende aandeel) waardeloos afgelopen. ${ }^{35} \mathrm{Bij}$ afwezigheid van de misleiding zou de optie op de expiration date met andere woorden 'in the money' zijn geweest.

Ongeacht het antwoord op de vraag hoe de hoogte van de schade van deze optiebelegger precies moet worden vastgesteld - daarover is veel meer te zeggen en dat gaat het bestek van dit artikel te buiten -, moet deze schade ons inziens worden aangemerkt als 'directe' of 'rechtstreekse' schade. Op dit eerste geval is de Poot/ABP-doctrine dus hoe dan ook niet van toepassing. Aangenomen dat de vennootschap met het misleiden van het beleggende publiek (jegens de maatman-belegger) toerekenbaar onrechtmatig heeft gehandeld (en/of dat de bestuurders hiermee toerekenbaar onrechtmatig hebben gehandeld), en aangenomen dat de optiebelegger bij het kopen van de optie direct of indirect is misleid, is denkbaar dat deze koersschade voor vergoeding in aanmerking komt. Als de opties echter niet door de vennootschap zelf zijn uitgegeven, kunnen de relativiteitseis van artikel 6:162 lid 1 jo. artikel 6:163 BW en de toerekening van de schade aan de aansprakelijke persoon of rechtspersoon ex artikel 6:98 BW voor de belegger lastig te nemen hindernissen zijn. Ook over deze hindernissen is in het kader

\footnotetext{
${ }^{35}$ Voor andere scenario's waarin de koper van een call-optie directe koersschade kan lijden als gevolg van misleidende berichtgeving, verwijzen wij naar het commentaar van E.V.A. Eijkelenboom \& A.C.W. Pijls bij Rb. Amsterdam 20 april 2016, ECLI:NL:RBAMS:2016:2191, Ondernemingsrecht 2017/45 (X/Koninklijke Ahold), alsmede naar hoofdstuk 5 van de in voetnoot 1 genoemde scriptie.
} 
van misleiding van optiebeleggers veel meer te zeggen, maar ook dat gaat het bestek van dit artikel te buiten.

In de situatie daarentegen waarin een derde (dit kan wederom de bestuurder van de vennootschap zijn) een norm schendt jegens de vennootschap met schade van de vennootschap tot gevolg, lijden - bij het bekend worden van deze schade - aandeelhouders afgeleide schade en kunnen optiebeleggers schade lijden die weer van de afgeleide schade van de aandeelhouder is afgeleid. Gedacht kan bijvoorbeeld worden aan de koper van een call-optie wiens optie ten tijde van de normschending van de derde 'in the money' is, maar welke optie als gevolg van deze normschending en de daardoor veroorzaakte daling van de aandelenkoers waardeloos afloopt. ${ }^{36}$ Aangezien de optie een financieel instrument is dat van de door de vennootschap uitgegeven aandelen is afgeleid, zouden wij deze koersschade van de optiebelegger willen aanmerken als 'dubbel afgeleid'. De vraag die zich meteen aandient, is of deze 'dubbel afgeleide' schade van de optiebelegger voor vergoeding in aanmerking komt, als de optiebelegger de derde hiervoor aansprakelijk stelt. Deze vraag beantwoorden wij in beginsel ontkennend. Ons belangrijkste argument hiervoor is dat vanwege de Poot/ABP-doctrine de afgeleide schade die de aandeelhouder als gevolg van de normschending van de derde (en de daardoor veroorzaakte schade bij de vennootschap) lijdt, in beginsel niet voor vergoeding in aanmerking komt als hij de derde hiervoor aansprakelijk stelt. Als de afgeleide schade van de aandeelhouder niet voor vergoeding in aanmerking komt, zouden wij - a fortiori - menen dat de 'dubbel afgeleide' schade van de optiebelegger evenmin voor vergoeding in aanmerking komt. In vergelijking met de aandeelhouder staat de optiebelegger namelijk veel verder van de vennootschap af. Dit geldt althans in ieder geval voor beleggers in opties die niet door de vennootschap zelf zijn uitgegeven, hetgeen voor verreweg de meeste opties het geval is. ${ }^{37}$

Aan deze redenering kan nog het volgende worden toegevoegd. In het klassieke Poot/ABPgeval is voor de derde die een norm jegens de vennootschap schendt zonder meer te voorzien

\footnotetext{
${ }^{36}$ Zoals in par. 6 opgemerkt, beperken wij onze analyse tot de koper van call-opties. In de situatie waarin een derde jegens de vennootschap een norm schendt met schade van de vennootschap tot gevolg, kan echter ook de schrijver van een zogenoemde 'put-optie' koersgerelateerde schade lijden. Gedacht kan bijv. worden aan het geval waarin de put-optie ten tijde van de normschending van de derde nog 'out of the money' is, maar welke optie als gevolg van deze normschending en de daardoor veroorzaakte daling van de aandelenkoers 'in the money' geraakt, waardoor zij op de expiration date alsnog wordt uitgeoefend. In dat geval wordt de schrijver van de put-optie door de normschending van de derde jegens de vennootschap benadeeld, terwijl de koper van deze optie hierdoor juist wordt bevoordeeld.

${ }^{37}$ In dit verband kan ook een vergelijking worden gemaakt met de situatie waarin een pandhouder op aandelen of een certificaathouder zich bevindt, indien door een derde schade wordt toegebracht aan de vennootschap met een daling van de aandelenkoers tot gevolg. Vgl. Kroeze 2004, p. 21-23; B.F. Assink, De 'economische werkelijkheid' in het Nederlandse ondernemingsrecht, WPNR 2014, afl. 7037, p. 1031-1044 en het commentaar van F.J.P. van den Ingh bij Hof Arnhem 21 oktober 1997, JOR 1998/3 (Veenbrink/Reuchlin). De schade die door deze belanghebbenden bij instandhouding van het vennootschapsvermogen wordt geleden, zou eveneens als 'dubbel afgeleid' kunnen worden aangemerkt. Een belangrijk verschil echter tussen enerzijds de pandhouder op aandelen of certificaathouder en anderzijds de belegger in call-opties op de desbetreffende aandelen is dat de schade van de optiebelegger vaak al definitief is geleden op het moment dat de vennootschap haar vermogensschade van de derde vergoed krijgt. Zijn als gevolg van de normschending jegens de vennootschap de opties namelijk waardeloos afgelopen, dan wordt de schade van de optiebelegger - anders dan die van de pandhouder op aandelen of certificaathouder - niet ongedaan gemaakt door het door de vennootschap ontvangen van schadevergoeding van de derde.
} 
dat hij daarmee ook schade berokkent aan de aandeelhouders. Volgens vaste rechtspraak van de Hoge Raad vormt dat op zichzelf echter geen argument om schending van een specifieke zorgvuldigheidsnorm aan te nemen in de verhouding derde versus aandeelhouder. Voor de derde die een norm schendt jegens een beursvennootschap is slechts in abstracto te voorzien dat hij daarmee ook optiebeleggers kan benadelen. Die derde hoeft namelijk niet in concreto te weten of überhaupt opties op de aandelen van de desbetreffende vennootschap zijn uitgegeven, en als hij dat wel weet, zal hij in de regel niet precies weten om wat voor opties het gaat en wat de relevante uitoefenprijzen van die opties zijn. In het klassieke Poot/ABP-geval wordt dus aangenomen dat - buiten het geval van opzettelijke benadeling van aandeelhouders voorzienbare benadeling van aandeelhouders geen schending oplevert van een specifieke zorgvuldigheidsnorm in de verhouding derde versus aandeelhouder. Daaruit dient te volgen dat in abstracto te voorziene benadeling van optiebeleggers al helemaal geen schending oplevert van een specifieke zorgvuldigheidsnorm in de verhouding derde versus optiebelegger.

Voor het geval waarin de optiebelegger de derde aanspreekt tot vergoeding van zijn 'dubbel afgeleide' schade, zou men op grond van het voorgaande kunnen zeggen dat de Poot/ABPdoctrine weliswaar niet direct op deze vordering van toepassing is, maar dat zij haar 'schaduw' wel over deze vordering 'vooruitwerpt'. Dan is er natuurlijk ook nog het geval waarin de 'dubbel afgeleide' schade van de optiebelegger beweerdelijk is veroorzaakt door een of meer bestuurders van de vennootschap en/of door een of meer hooggeplaatste managers, en waarin de optiebelegger van de vennootschap vergoeding vordert van zijn 'dubbel afgeleide' schade. ${ }^{38}$ De optiebelegger zal zich dan op het standpunt stellen dat de handelingen van de bestuurder(s) en/of manager(s) aan de vennootschap kunnen worden toegerekend. Hoewel de Poot/ABPdoctrine ook op dit geval niet van toepassing is, zijn wij van mening dat de 'dubbel afgeleide' schade van de optiebelegger evenmin voor vergoeding in aanmerking komt als hij - in plaats van de bestuurder(s) en/of manager(s) - de vennootschap hiervoor aansprakelijk stelt. Onze redenering is vergelijkbaar met die van het gerechtshof Amsterdam in de WCAM-beschikking inzake de Fortis-schikking voor het geval waarin de aandeelhouder de vennootschap aanspreekt tot vergoeding van zijn afgeleide schade (zie par. 4), maar wel met de belangrijke kanttekening dat de overweging dat aandeelhouders worden beschermd doordat hun juridische middelen ten dienste staan om invloed uit te oefenen op het beleid van de vennootschap of dat eventueel ter toetsing voor te leggen aan de rechter, in het geval van de gedupeerde optiebelegger uiteraard niet opgaat. ${ }^{39}$

Dan rijst tot slot nog de vraag of er ook situaties denkbaar zijn waarin optiebeleggers door hen geleden 'dubbel afgeleide' schade toch - met succes - op de derde kunnen verhalen die jegens de vennootschap een norm heeft geschonden. Een dergelijke vergoeding achten wij slechts denkbaar, als de derde jegens de optiebelegger een specifieke zorgvuldigheidsnorm heeft geschonden. Het gaat hierbij om zeer uitzonderlijke situaties. Gedacht kan bijvoorbeeld worden aan het geval waarin door de derde handelingen zijn verricht met het oogmerk om

\footnotetext{
${ }^{38}$ Vgl. par. 4 voor het geval waarin de aandeelhouder van de vennootschap vergoeding vordert van zijn afgeleide schade.

${ }^{39}$ Hof Amsterdam 13 juli 2018, ECLI:NL:GHAMS:2018:2422 (WCAM-procedure Fortis-schikking), r.o. 5.32 e.v.
} 
bepaalde - bij deze derde bekende - optiebeleggers in die hoedanigheid schade te berokkenen. ${ }^{40}$ Die handelingen moeten daadwerkelijk hebben geleid tot schade van de vennootschap, tot - met die schade van de vennootschap corresponderende - afgeleide schade van de aandeelhouder, en daarmee dus uiteindelijk tot - met die afgeleide schade van de aandeelhouder corresponderende - 'dubbel afgeleide' schade van de optiebelegger.

Als in de verhouding derde versus optiebelegger inderdaad de schending van een specifieke zorgvuldigheidsnorm kan worden aangenomen, moet - net als in de situatie waarin sprake is van schending van een specifieke zorgvuldigheidsnorm in de verhouding derde versus aandeelhouder - daarnaast nog worden gekeken of doelmatigheidsargumenten c.q. beleidsmatige afwegingen de facto aan vergoeding in de weg staan. Wij verwijzen in dit verband naar de in paragraaf 5 genoemde gezichtspunten. Worden deze gezichtspunten toegepast op de situatie waarin jegens de optiebelegger een specifieke zorgvuldigheidsnorm is geschonden, dan ontstaan belangrijke verschillen met de situatie waarin jegens de aandeelhouder een dergelijke norm is geschonden:

1) Anders dan de aandeelhouder die afgeleide schade lijdt als gevolg van de normschending van een derde jegens de vennootschap, kan de optiebelegger die als gevolg van zo'n normschending 'dubbel afgeleide' schade lijdt, deze schade niet vergoed krijgen door het betalen van schadevergoeding van de derde aan de vennootschap, indien zijn optie in de tussentijd waardeloos is afgelopen. De schade van de optiebelegger is door het waardeloos aflopen van de optie dan immers definitief geworden.

2) De consequentie hiervan is dat de optiebelegger wiens optie waardeloos is afgelopen nooit dubbele schadevergoeding kan ontvangen. Dit kan anders liggen voor bijvoorbeeld de optiebelegger die de optie wel heeft kunnen uitoefenen en aldus aandelen in de vennootschap heeft verkregen, maar wiens optie als gevolg van de normschending van de derde jegens de vennootschap en de daardoor veroorzaakte daling van de aandelenkoers in mindere mate 'in the money' was dan zij bij afwezigheid van deze normschending zou zijn geweest.

3) Daar waar gedupeerde aandeelhouders de mogelijkheid hebben om via hun toekomende zeggenschapsrechten invloed uit te oefenen op het besluit van de vennootschap om door haar geleden schade al dan niet op de derde te verhalen, hebben gedupeerde optiebeleggers deze mogelijkheid niet (althans niet in hun hoedanigheid van (ex-)houder van een call-optie).

4) Het argument van mogelijke crediteurenbenadeling kan aan de orde zijn, zowel in de situatie waarin de aandeelhouder van de derde vergoeding vordert van zijn afgeleide schade, als in de situatie waarin de optiebelegger van de derde vergoeding vordert van zijn 'dubbel afgeleide' schade. Maar zolang de betrokken vennootschap voldoende solvent is, is dit argument minder relevant.

5) Aangezien het aantal geschreven opties in theorie onbeperkt is (voor de meeste opties geldt dat zij worden 'gecreëerd' door beleggers en dat de vennootschap hier geen enkele 40 Vgl. HR 16 februari 2007, ECLI:NL:HR:2007:AZ0419, NJ 2007/256 m.nt. J.M.M. Maeijer (Tuin
Beheer/Houthoff). 
controle over heeft), is in theorie niet uitgesloten dat het toekennen van een rechtstreeks vorderingsrecht aan optiebeleggers zal leiden tot een groot aantal vorderingen tegen de derde. Praktisch gezien legt dit argument echter weinig gewicht in de schaal, omdat zoals wij hiervoor al opmerkten - het aannemen van schending van een specifieke zorgvuldigheidsnorm in de verhouding derde versus optiebelegger zeer uitzonderlijk is, en als van zo'n normschending al sprake is, het aantal beleggers jegens wie de schending wordt aangenomen doorgaans zeer beperkt zal zijn.

Op basis van het bovenstaande concluderen wij dat de 'dubbel afgeleide' schade van de optiebelegger eerder voor vergoeding in aanmerking komt als de derde jegens hem een specifieke zorgvuldigheidsnorm heeft geschonden, dan dat de 'gewone' afgeleide schade van de aandeelhouder voor vergoeding in aanmerking komt als jegens hem zo'n zorgvuldigheidsnorm is geschonden. De doelmatigheidsargumenten die zich tegen rechtstreekse vergoeding (kunnen) verzetten, zijn bij de benadeelde optiebelegger namelijk minder pregnant aanwezig dan bij de benadeelde aandeelhouder.

\section{$8 \quad$ Conclusie}

In navolging van achtereenvolgens Kroeze en Assink beschouwen wij afgeleide schade als een feitelijk, beschrijvend begrip. Afgeleide schade is de schade die een aandeelhouder lijdt door waardevermindering van zijn aandelen, wanneer en voor zover deze waardevermindering het gevolg is van schade die aan de vennootschap is toegebracht. In deze opvatting hoeft de schade van de vennootschap niet het gevolg te zijn van de normschending van een derde jegens de vennootschap om voor de daarmee corresponderende waardedaling van de aandelen van 'afgeleide schade' te kunnen spreken. Daarmee wordt een scheiding aangebracht tussen gevallen van afgeleide schade die wel onder de Poot/ABP-doctrine vallen en gevallen die daar niet onder vallen. In tegenstelling tot afgeleide schade loopt directe of rechtstreekse schade niet via het vermogen van de vennootschap. Van directe schade is bijvoorbeeld sprake als de vennootschap het beleggende publiek misleidt en beleggers daardoor aandelen in die vennootschap tegen een geïnflateerde prijs kopen.

De aandeelhouder kan in beginsel alleen door hem geleden directe schade rechtstreeks op de vennootschap, de bestuurder(s) en/of andere betrokken derden verhalen (ervan uitgaande dat steeds aan alle aansprakelijkheidsvereisten van O.D. is voldaan). De Poot/ABP-doctrine staat er echter aan in de weg dat de aandeelhouder afgeleide schade die het gevolg is van de normschending van een derde jegens de vennootschap rechtstreeks op deze derde kan verhalen. Hoewel de Poot/ABP-doctrine niet van toepassing is op het geval waarin de afgeleide schade van de aandeelhouder beweerdelijk is veroorzaakt door een of meer bestuurders van de vennootschap en/of door een of meer hooggeplaatste managers, en waarin hij van de vennootschap vergoeding vordert van zijn afgeleide schade, doet haar ratio volgens ons ook in dat geval van zich spreken. Van een uitzondering op de hoofdregel van het Poot/ABP-arrest kan sprake zijn als de aandeelhouder aannemelijk maakt dat de derde jegens hem een specifieke zorgvuldigheidsnorm heeft geschonden. De schending van zo'n specifieke zorgvuldigheidsnorm is een noodzakelijke voorwaarde waaraan moet zijn voldaan, wil de afgeleide schade van de aandeelhouder eventueel voor vergoeding in aanmerking komen. Komt 
schending van zo'n specifieke zorgvuldigheidsnorm inderdaad vast te staan, dan kan het echter nog steeds zo zijn dat aan de Poot/ABP-doctrine ten grondslag liggende doelmatigheidsargumenten c.q. beleidsmatige afwegingen zich tegen vergoeding van deze afgeleide schade verzetten.

Ook de optiebelegger kan koersgerelateerde schade lijden als gevolg van (1) misleidende berichtgeving van de vennootschap, of (2) de normschending van een derde jegens de vennootschap. In het eerste geval moet deze koersschade worden aangemerkt als 'directe' of 'rechtstreekse' schade. Onder bepaalde omstandigheden is denkbaar dat deze koersschade voor vergoeding in aanmerking komt. In het tweede geval kunnen optiebeleggers zogenoemde 'dubbel afgeleide' schade lijden. Met een beroep op de Poot/ABP-doctrine en een bijbehorende redenering naar analogie betoogden wij dat deze 'dubbel afgeleide' schade van de optiebelegger in beginsel niet voor vergoeding in aanmerking komt, als de optiebelegger de derde hiervoor aansprakelijk stelt. Vergoeding van deze 'dubbel afgeleide' schade achten wij slechts denkbaar in het uitzonderlijke geval waarin schending van een specifieke zorgvuldigheidsnorm kan worden aangenomen in de verhouding derde versus optiebelegger. Komt schending van zo'n specifieke zorgvuldigheidsnorm niettemin vast te staan, dan kan het nog steeds zo zijn dat aan de Poot/ABP-doctrine ontleende doelmatigheidsargumenten c.q. beleidsmatige afwegingen zich tegen vergoeding verzetten. Wel kan de weging van deze argumenten hier anders uitvallen dan in de situatie waarin schending van een specifieke zorgvuldigheidsnorm wordt aangenomen in de verhouding derde versus aandeelhouder. De verklaring hiervoor is dat belangrijke verschillen bestaan tussen enerzijds de benadeelde optiebelegger en anderzijds de benadeelde aandeelhouder. Zo kunnen optiebeleggers, anders dan aandeelhouders, niet via hun toekomende zeggenschapsrechten invloed oefenen op het besluit van de vennootschap om door haar geleden schade al dan niet op de derde te verhalen. Ook is de 'dubbel afgeleide' schade van de optiebelegger eerder definitief dan de afgeleide schade van de aandeelhouder, waardoor de kans kleiner is dat de optiebelegger dubbele schadevergoeding ontvangt dan dat de aandeelhouder dubbele schadevergoeding ontvangt. 